\title{
6
}

\section{FEAR AND LOATHING IN THE RADICAL REFORMATION}

\section{David Joris as the prophet of emotional tranquillity, 1525-1556}

\author{
Gary K. Waite \\ UNIVERSITY OF NEW BRUNSWICK
}

\section{Emotions in the Reformation}

For centuries, historians of the Reformation have argued, sometimes vociferously, over the exact meaning and significance of the theological reforms of Protestant leaders for the crystallization of religious and political identities in the sixteenth century. ${ }^{1}$ Since the 1970 s, scholars have explored how these ideas were also expressed orally, received aurally, and interpreted differently by various individuals and groups. ${ }^{2}$ Much more recently, historians have found ways to uncover how parishioners utilized their senses in worship. ${ }^{3}$ Similarly, current attention on emotions in the sixteenth century has revealed much about how Europeans experienced the Reformation. ${ }^{4}$ Much of their behaviour has often belied both official dogma and historical explanation.

An explanation for this apparent anomaly can perhaps be found in the work of the great Dutch cultural historian Johan Huizinga, who in 1924 described the hyper-emotionality of late medieval people as a distinction of the era, as people oscillated between 'despair and distracted joy, between cruelty and pious tenderness'. If correct, then we need to examine how or if the Reformation moderated such emotional extremes. The evidence of the religious violence of the sixteenth century alone would suggest it did not. ${ }^{6}$ Instead, it appears that the Reformation period was even more emotionally charged than the late medieval, as efforts to live up to new doctrinal and behavioural standards caused escalated levels of ecstasy and anguish. ${ }^{7}$ The passions aroused by religious antipathy encouraged the use of demonizing rhetoric against various groups of dissenters, as well as populist uprisings and mob violence. ${ }^{8}$ The fear of God and his punishments for sin were behind both the religious persecution and the large-scale witch-hunting of the century. ${ }^{9}$ Churchmen may have justified the prosecution of heretics in rational terms as excising a cancer from the body politic or 
cleansing a community from the pollution of blasphemy, ${ }^{10}$ but behind it all was a profound dread of God's wrath. ${ }^{11}$

Some major actors in the Reformations have left behind a record of their feelings, most famously Martin Luther who constantly reported on his anxieties over the Devil and death, and on joys over his pleasure in his dear Katie. ${ }^{12}$ Most did not. Both Luther and Calvin encouraged an interiorized faith, while Calvin's followers pursued a process of self-examination to gauge their spiritual health and standing. Some Puritans took this to the extreme of searching agonizingly for signs of being among the elect, such as feeling sorrow for sin and fear of damnation. Many alternated between deep despair and thoughts of suicide and intense joy, leading Paola Baseotto to suggest that the difference between Elizabethan 'puritans' and Anglicans was not so much one of doctrine but of 'emotionology'. ${ }^{13}$

The Puritans were not alone in confronting extreme emotions arising from spiritual self-examination. For instance, in 1524, a South German, Jörg Haugk von Jüchsen, described how believers needed to climb the seven steps towards spiritual conformity with Christ that would overcome the 'spirit of fear' of humans and instil the perfect 'fear of God'. ${ }^{14}$ This true fear, he continued, leads to 'anxious questioning, to an examination of oneself and of God in all things', and ultimately to full understanding. Composed during the height of the German Peasants' War and printed by the mystical Anabaptist Hans Hut, this tract reveals the intense dread felt by dissenters and their desire to quell it. Such a quest was even more prominent for the Dutch Anabaptist and spiritualist David Joris (1501-1556), who advocated a similarly stepped program of spiritual examination and progress and who experienced tremendous emotional extremes. In his case, however, these came first and foremost from the external pressures of persecution, and his scheme of spiritual development emphasized achieving peace and tranquillity by means of 'rising above' the 'fear of man' that led to emotional instability, and relying solely on the perfect 'fear of God' to achieve calm. In this way, he offered a solution by which the devout could rest assured that they were part of God's chosen, while avoiding the unceasing turmoil experienced by later Puritans.

\section{Dutch Anabaptists and David Joris}

Joris and his Anabaptist colleagues were the most severely persecuted religious group in the sixteenth century. Catholic and Lutheran polemicists produced volumes of hate literature linking Anabaptists to the Devil and sedition, while Calvinists used less demonizing language to condemn their sectarianism. Luther thought they were mad, not only for their irrational beliefs and ecstatic behaviour, but also for their willingness to die for their beliefs. ${ }^{15}$ All of this confirmed the Anabaptists' self-image as the persecuted children of God, encapsulated in their many martyr books. ${ }^{16}$ Without political allies, Anabaptists faced extreme levels of insecurity and turmoil as they sought refuge in foreign lands or endured 
harsh punishment if they stayed in their territories. At least 2,000 died for their beliefs, most of them in the Catholic Habsburg domains, but they were prosecuted in Lutheran and Reformed territories as well. In the Habsburg Netherlands, hundreds of Anabaptists were executed and hundreds more accorded lighter punishment or forced into exile, most of them between 1535 and $1570 .^{17}$

Of all of these Anabaptists, Joris inspired the greatest hatred from opponents, as well as intense devotion from followers. ${ }^{18} \mathrm{He}$ was forced into exile three times, the first a three-year banishment from Holland in 1528, the second a move to a noble manor near Antwerp in 1539, and finally a hurried flight to Basel in 1544 after Joris's locale was revealed by an associate in the torture chamber. In Basel, Joris resided with his noble patrons until he died of natural causes in 1556. These latter moves coincided with Joris's transition away from Anabaptism and towards spiritualism and to a scheme of inner spiritual development that made spiritual perfection possible. By defeating the lusts of the old Adam within, believers could reach a state where they would be unaffected by temptation. As the Holy Spirit moved within them, they would be so caught up in the love of God that they would not fear humans, but instead express that divine love in the love of neighbour. Religious externals, including doctrine, rites, and sacraments, were, moreover, of little consequence compared to their inner significance. Joris also chided governmental officials for persecuting people for such inconsequential matters. His supporters were completely devoted to him, many dying to keep his whereabouts secret. To support them, Joris wrote and published well over 200 tracts and books and hundreds of letters. Here we will focus our efforts on exploring only a few key works, especially an extraordinary biography that recounts Joris's life up to his flight from Holland in 1539. During this period, Joris struggled to maintain his sanity while experiencing feelings of apocalyptic excitement and anxiety so powerful they produced ecstatic, visionary episodes. This biography reveals that these were not so much self-induced from intense introspection, but the result of the truly frightening persecution and fugitive existence that pushed him to a form of inner exile. The spiritually renewed individuals would be so filled with the love of the divine that they would achieve a state of freedom from sin and of tranquillity in the face of external turmoil. Joris was not unique in seeking emotional calm during this tumultuous century, as other spiritualists came to similar conclusions. As detailed recently by Mirjam van Veen, Dirck Volckhertsz Coornhert struggled with sorrow, loneliness, and nearly constant fear for his and his wife's safety when in his exile from Haarlem, and experience of these emotions helped push him towards a greater emphasis on toleration and Stoic-like calm. ${ }^{19}$ In other cases, religious zeal and exile combined could lead to madness, as seen in Hans de Waardt's portrayal of the spiritualistic humanist and self-acclaimed prophet Justus Velsius Haganus. ${ }^{20}$

Spiritualism was particularly prominent in the Lower Rhineland region, thanks to the influence of mysticism and Erasmian humanism, and Dutch Anabaptism became a prime carrier. ${ }^{21}$ Inspired by the South German apocalyptic prophet Melchior Hoffman, Dutch Anabaptists listened for the voice of the Spirit while awaiting the return of Christ in the Last Days. ${ }^{22}$ In 1531 , Hoffman 
suspended baptisms to halt governmental persecution, but two years later his self-acclaimed successor Jan Matthijs proclaimed Christ's return would occur in 1534 in the Westphalian city of Münster. To experience the joy of seeing Christ descend to earth, thousands of Melchiorites sold their property, left their homes, and endured privation and governmental prosecution. One can only imagine their emotional turmoil, as well as that of the orthodox, who feared divine retribution should heresy be tolerated. ${ }^{23}$ These were the actions of people caught up in excitement, hope, and fear. An example of the power of such emotions occurred on the evening of 11 February 1535, when a small group of eleven Anabaptists, including four women, were inspired by their prophet Heynrick Heynricxz to remove and burn their clothes in an upper room of an Amsterdam house and then run out onto the streets of the city, crying 'woe, woe over the world and the godless', proclaiming the 'naked truth'. ${ }^{24}$ Even in prison, the defendants refused the offer of clothing and behaved bizarrely in the courtroom, leading the president of the Court of Holland, Gerrit van Assendelft, to contemplate demonic possession as the cause. ${ }^{25}$ In the end, he determined they were neither possessed nor mad, and they were punished as heretics. To be caught up in the apocalyptic moment was, therefore, not seen as inherently insane, but the humanist Van Assendelft certainly regarded it as allowing the emotional faculties to overwhelm the rational (Figure 6.1).

After a debilitating two-year siege, Anabaptist Münster fell in June 1535. Governmental prosecution of Anabaptist heresy understandably escalated, as the authorities feared further insurrections. For those Anabaptists who remained in the movement, the persecution raised the level of despair and anger to the boiling point, as seen in the retributive violence of the Batenburgers. ${ }^{26}$ For those who recanted their beliefs, we can only guess at their feelings, since most have disappeared from the historical record. But they undoubtedly included disillusionment at the failure of the prophecies, guilt at abandoning fellow believers, and fear of God's anger over their apostasy. One exception is Obbe Philips, who recorded his feelings some twenty-five years after Münster. Having long since abandoned his Anabaptist identity, Obbe blamed the debacle on the overzealousness of its self-acclaimed prophets and on their tactic of condemning all opponents as godless and devilish in such 'frightful' terms 'that the hair on a man's head would stand on end'. ${ }^{27}$ From their naivete they unquestioningly accepted dreams and fantasies, 'with no little joy and expectation'. ${ }^{28}$ They were, he concludes, driven to desperation by persecution and more easily caught up in the apocalyptical excitement:

O how many times were some of us so distressed to death that the heart in our bodies turned cold, and we did not know where to turn, nor what best to do; the whole world pursued us to death with fire, water, sword, and bloody tyranny for our belief. The prophecies deceived us on all sides... Were it not for the love I felt for the simple hearts who were daily misled by the false brethren, I would long ago have left them and 


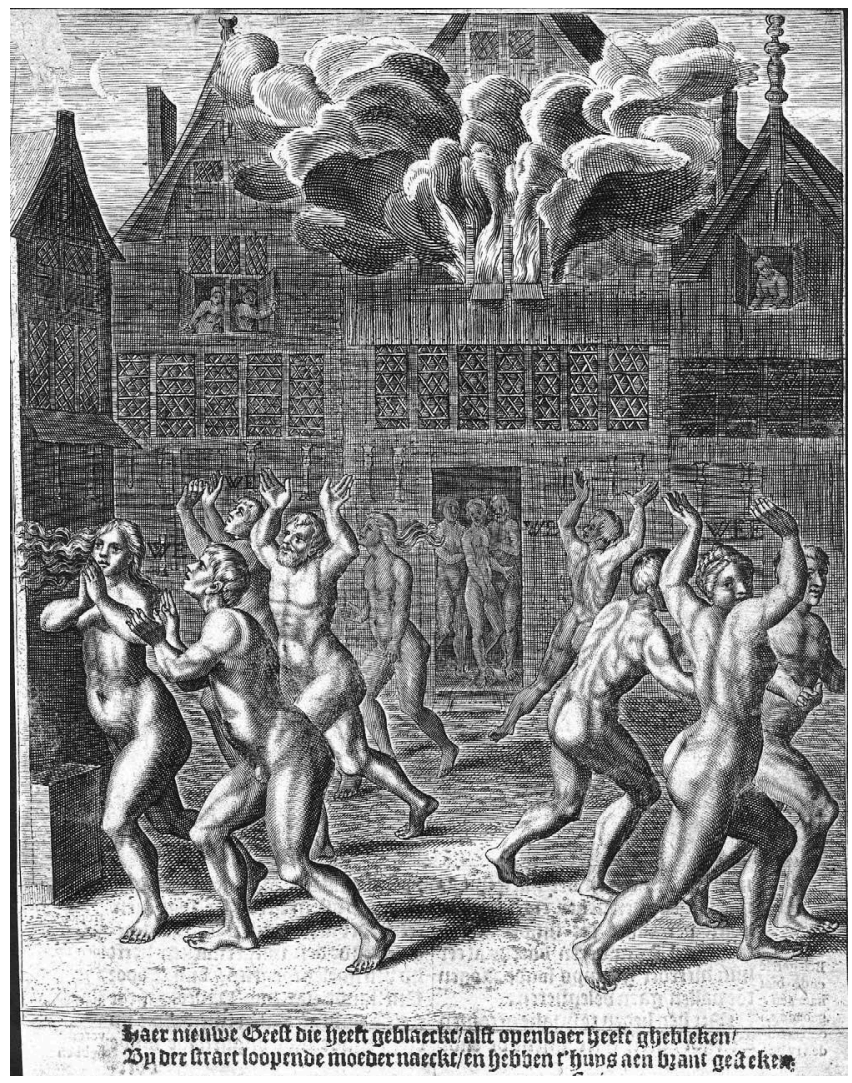

FIGURE 6.1 After Barent Dirksz (painting destroyed in 1652), The naked runners of Amsterdam, copper etching, in Lambertus Hortensius, Het boeck van den oproer der wederdooperen (Enkhuisen, 1624), 18r. Allard Pierson, University of Amsterdam, Kerkelijke Collecties, KF 61-5256.

departed from all my acquaintances... Indeed, I may well say with truth that my love of the brethren in the zeal for the house of the Lord very nearly engulfed me. ${ }^{29}$

Writing years after the fact, Philips was still 'miserable of heart' for his role in encouraging people to join the Anabaptists and for having commissioned Joris and Menno Simons as leaders.

Those who were caught up in the judicial system have left indirect traces of a range of intense feelings in court records, martyr accounts, and letters written to family and friends. These have yet to be seriously mined with respect to the history of emotion. For example, Anna Jans of Rotterdam, one of only three known followers of Joris to be included in the Martyr's Mirror (Mennonites, who despised Joris, may not have known about Jans's true affiliation), wrote a letter 
to her young son as she faced execution. ${ }^{30}$ The letter encourages the boy not to fear humans but only God, the sole path to happiness, and to flee the world and love God. On the surface, the letter is not particularly emotive, but one wonders how her son felt at reading it when he was older, especially the mention of how she 'sealed this with her blood'. ${ }^{31}$ The image by the seventeenth-century engraver Jan Luyken of Anna being led to the scaffold and giving her son Isaiah and a bag of money to a man who would raise him is heartrending, as is seen in the faces of the spectators (Figure 6.2). Or, there is the story of the sisters-inlaw Maria and Ursula van Beckum, two other supporters of Joris in the Martyr's Mirror who were executed in Overijssel in 1544. The account is filled with the diabolical anger of the prosecutors and the godly patience, fear, and joy of the accused. Luyken's image reveals a model of calmness in the sister at the stake, and a look of pity on her compatriot (Figure 6.3). ${ }^{32}$

The execution of these young noblewomen inspired further emotional responses: a number of their friends and family, calling themselves the 'Children of Emlichheim', were so enraged that in late August 1548 they conducted

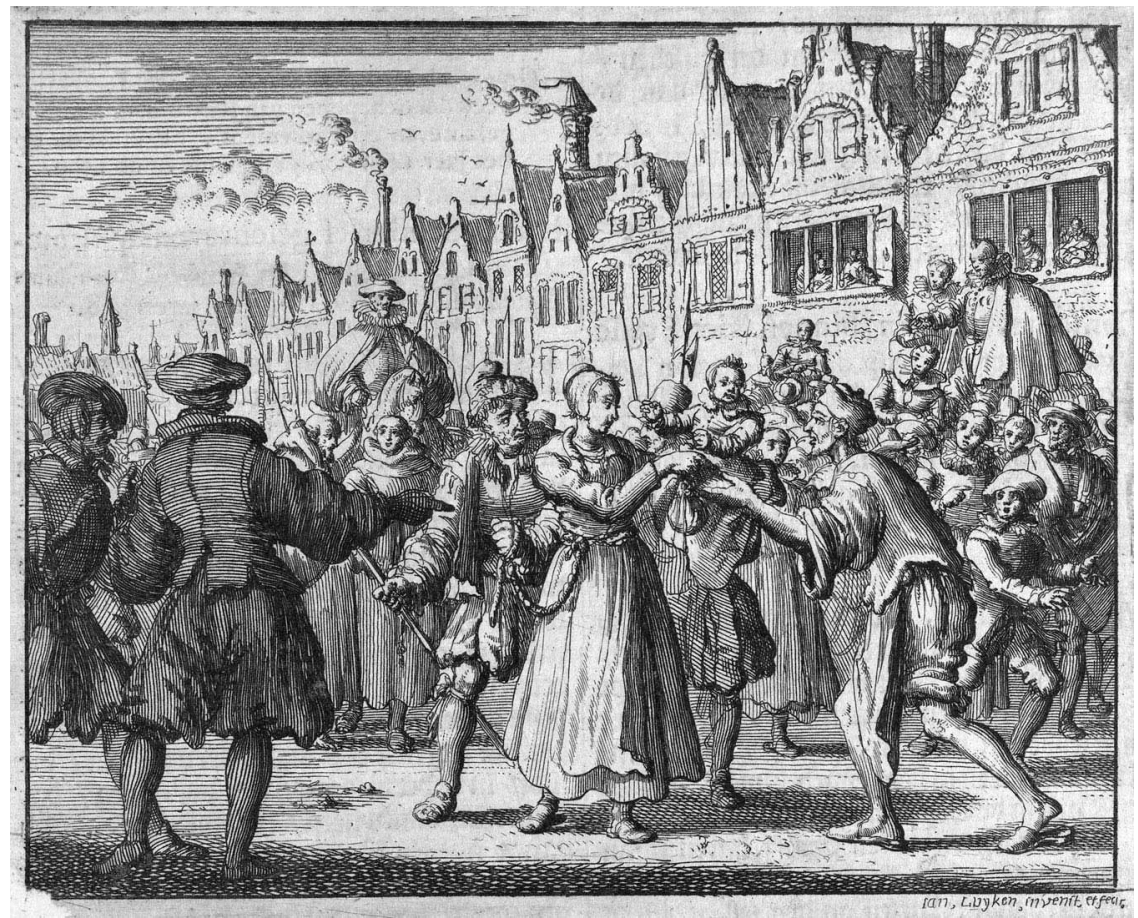

FIGURE 6.2 Jan Luyken, Anna Jans hands over her son, the later Isaiah de Lind, to a baker, 1539, engraving, in Tieleman Jansz van Bracht, Het bloedig tooneel, of Martelaers spiegel (Amsterdam, 1685), 2: 143. Allard Pierson, University of Amsterdam, Kerkelijke Collecties, Prent K 904a. 


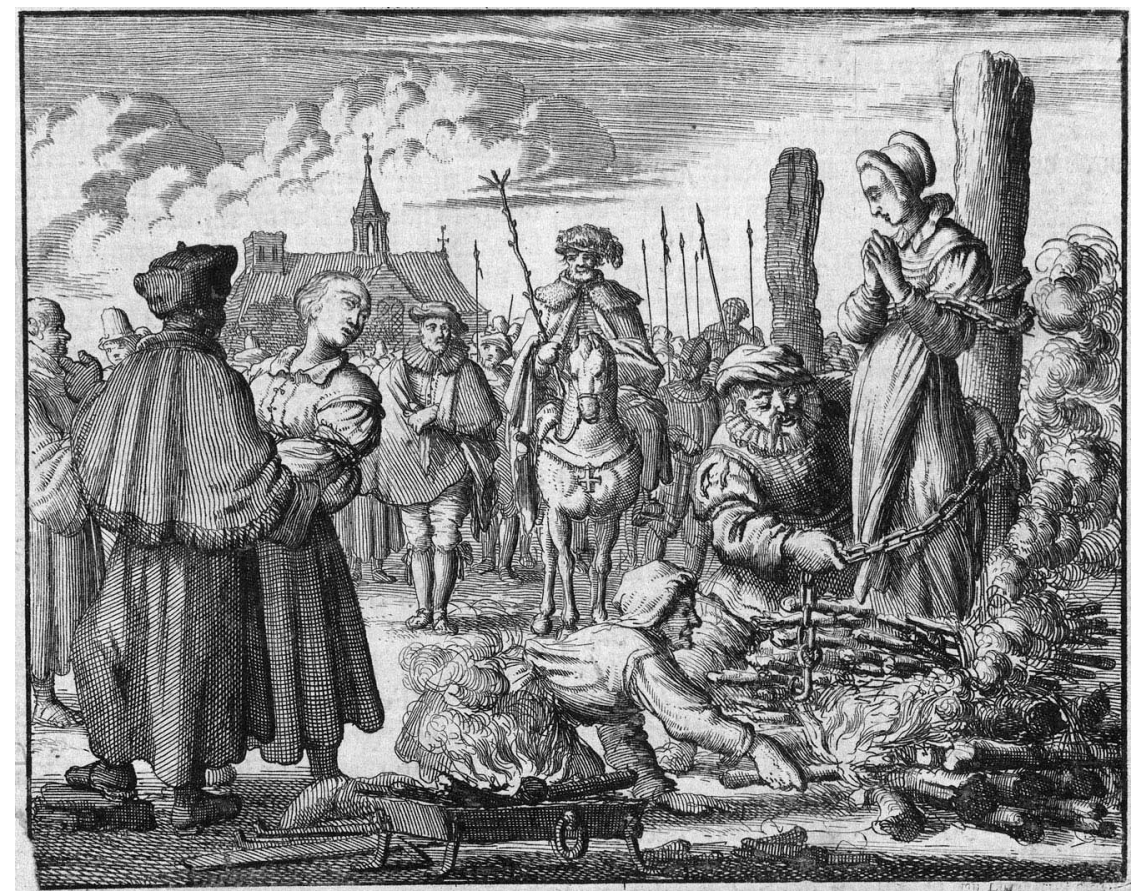

FIGURE 6.3 Jan Luyken, The Sisters Maria and Ursula van Beckum on the pyre at Delden, 1544, engraving, in Tieleman Jansz van Bracht, Het bloedig tooneel, of Martelaers spiegel (Amsterdam, 1685), 2: 65. Allard Pierson, University of Amsterdam, Kerkelijke Collecties, Prent K 904a.

a campaign of vengeance by stabbing livestock and committing acts of arson that led in turn to widespread fears of conspiratorial terrorist gangs. ${ }^{33}$ Elsewhere, governmental persecution of Anabaptists was inspiring both pity and anger among audiences, leading some magistrates to suppress public executions. ${ }^{34}$ While the scribes of the court records made few references to emotions in the torture chamber, the writers of the martyrological accounts did, with the intention of moving readers to deeper commitment of their faith. ${ }^{35}$

\section{David Joris as the prophet of emotional tranquillity}

The Joris biography falls into the same genre as the martyr accounts. The writer offers considerable insight into Joris's mental state, hence he must have been very close to the prophet. ${ }^{36} \mathrm{He}$ clarifies that he is describing not the "conduct of [Joris's] outward life and nature', but, like most hagiographies, is focused on the 'inner heart' of his subject. ${ }^{37}$ As a youth, Joris allegedly had no 'desire' for studies and was passionate instead about art and religion. ${ }^{38}$ His parents apprenticed him to a glass-painter, although at his father's death Joris was placed with 
a merchant to learn a more lucrative career. In this wealthy man's home, Joris battled temptations to 'a money God' and eventually turned down the prospect of wealth to embark with fellow glass-painters on a journeyman's tour through Flanders, Valencia, and England. ${ }^{39}$ As an artist, Joris would have been trained in how to portray the inner emotional state of the subject on canvas or glass, and this gave him a deep appreciation of the emotive side of religious experience. ${ }^{40}$

In 1524, Joris returned to the Low Countries, setting up shop in Delft. Here he was inspired by evangelical sermons, becoming 'consumed' by the reform message 'like the working of physical love', so much so that 'he nearly drowned in this knowledge'. This the biographer describes as a zeal that 'struck David Joris's heart ... with hunger and longing' and grieving over his 'godless, fleshly, vain life'. In this quest for spiritual salvation and the anger over ecclesiastical abuses, Joris was not unusual, as these were commonplaces for Protestants. Disregarding the love that he had for his wife, Dirkgen Willem, and their young child, Joris took the risky step in 1528 of preaching publicly against idolatry and the veneration of the Virgin Mary while in front of participants in the Ascension Day procession. He was arrested, jailed, and sentenced to a whipping, the boring of his tongue and expulsion from the city; thanks to family connection to the elites of the city, Joris avoided a death sentence. ${ }^{41} \mathrm{He}$ seems to have endured this exile in Emden, East Frisia, where he heard Hoffman preach. Upon his return to Holland, Joris allegedly resisted efforts to persuade him to join the Anabaptists. Yet, he was 'very confused in his soul' because he admired their zeal. ${ }^{42}$ Then, at the height of the apocalyptic excitement of Münster, one Anabaptist woman struck an emotional chord with him by appealing to the courage of those who were paying for their faith with their blood, at which 'he was struck down in his most inward being' and relented, undergoing rebaptism in the winter of $1534 / 5$ at the hands of Obbe Philips. ${ }^{43}$ Now back in harm's way, Joris's struggles with anxiety began in earnest, as he 'had to run sometimes here, other times there', leaving behind wife and children and putting his life in the hands of both friends and strangers. On the run, he dashed off spiritual songs, one composed in the bushes behind an inn, that encouraged believers with the expectation of Christ's arrival while admonishing them to be ready to die, as 'these are truly dangerous times, in which the elect of God stand in anxiety'. 44

The biography's vivid descriptions of the intense pressure on Joris accord with what we know about governmental efforts to catch him. In 1538 and 1539 , over 100 of his supporters were judicially interrogated and executed, but until 1544, none divulged his whereabouts, because 'his disciples loved and valued him so much that they suffered all the pains of martyrdom on his account'. ${ }^{45}$ These included his mother, who was executed, and his wife, who somewhat mysteriously was released. ${ }^{46}$ Joris therefore lived in constant fear of discovery, arrest, torture, and execution; a price was put on his head, and spies and informants were hired to find him. His biographer therefore emphasizes 
Joris's nearly constant anxiety over the safety of his wife and children, from whom he was often separated. He also describes Joris's intense pain and guilt at the suffering of his followers, knowing that they were being tortured and executed on his account. Psychological studies of 'survivors' guilt' have revealed its powerful effects, including, according to Robert Jay Lifton, depression and 'a struggle to achieve a magical form of vitality and power over death'. ${ }^{47}$ This latter was in fact something of a preoccupation in Joris's early writings. ${ }^{48}$ These can be understood only in the context of guilt, anxiety, and outright terror that their author lived through. Such guilt feelings were not unique to Joris. His biographer describes a meeting between Leonard van Dam and a knight of Guelders, whose feelings of guilt for having slain a Münsterite during the siege led him to offer Joris a refuge. ${ }^{49}$

Anxiety is therefore a major theme of Joris's biography, as its author notes:

but there arose a great dissension among these people [Anabaptists], for one wanted it one way, another the other way; some put forward strange, unusual things, others, hypocrisy; and there was on every side nothing but strong emotions. Everyone was in anxiety, worry and calamity, not knowing who they should follow. ${ }^{50}$

Many pleaded with Joris to take leadership, but he resisted, claiming he felt 'no calling or power'. Fear of capture, torture, and execution competed with the fear of disobeying God in the Last Days. ${ }^{51}$ Since Joris had not been a leader of the now-discredited Münsterite movement, he was seen by many as a good choice to lead the Anabaptist remnant in a non-violent direction, although some clearly hoped he would restore the Anabaptist kingdom of God, at least in a spiritual fashion.

In 1536, Joris met with other Anabaptist leaders in a place identified as Boeckholt, Westphalia. The trip was fraught with danger, as the authorities were hunting down seditious heretics and militant Anabaptists considered him a traitor for opposing violence. The event was a watershed in Joris's religious career, as he forged a compromise agreement between the militant and non-violent Anabaptist factions that thrust him into the forefront of the movement. From this moment on, confidence in his calling increased, although it remained mixed with moments of extreme doubt and fear. He prayed persistently for divine assistance to enter into a state of spiritual calm, despite the danger constantly around him and forced absences from wife and family - for which 'even a heart of stone would have pitied them'. ${ }^{2}$ In 1539, in fact, the authorities used both Dirckgen and her children as bait to entrap Joris. The tactic nearly worked, as Joris's travelling companions had to physically restrain the prophet from jumping off the wagon to give himself up, to achieve the release of his family. ${ }^{53}$

Joris's anxiety at times manifested itself in physical symptoms, and there were moments when 'he could not be left alone'. ${ }^{4}$ Even when in relative safety among supporters, fear and other 'temptations' could overwhelm him, 
and he was often 'forced to completely quiet himself (whenever the temptations fell on him) among the people, as if he was standing behind a curtain and had to hide. He had to swallow all sorts of pills, which happened to him many times'. ${ }^{55}$ What those pills were we do not know, but melancholia was a broad diagnosis associated with madness or convulsions, and in the sixteenth century was believed to afflict men as well as women. ${ }^{56}$ Temptation to sexual improprieties was also intense, although the biographer claims that Joris and one woman in particular, since identified as the aforementioned Anna Jans of Rotterdam, succeeded in their struggles to remain chaste, a tough matter for Joris who was born of 'the complexion of love', with 'an affectionate disposition', and 'liked to love'. There are, however, good reasons to doubt the biographer's claims of chastity. ${ }^{57}$ As will be noted shortly, a later critic, the Cambridge Platonist Henry More, was similarly sceptical, diagnosing Joris as having a sanguine temperament that predisposed him to sexual excess.

In the midst of such terror and temptation, it is understandable that Joris would seek 'to become free from all worry', which, the biographer added, meant freedom from 'all anxiety, danger, pain, and lack of desire or feebleness'. Like late medieval mystics, Joris pursued divine love as an antidote to fear, 'for he knew that when the heart was surrounded with stronger love, it would permit no incitement, rod, or chastisement which God did not permit' ${ }^{58}$ The constant anxiety also provoked in him a deep concern about light-heartedness, especially in the usage of the name of God, which partly motivated his efforts to communicate with Jews. ${ }^{59}$

After the 1536 meeting of Anabaptists at Boeckholt, Joris experienced visionary episodes that provided him with confidence in his mission as God's chosen prophet, which had earlier often eluded him. In one of the first of these episodes, during a prolonged period of arduous prayer, Joris suddenly stood 'enraptured as if he had left his body, so that he did not know if he was living or dead'. He then saw the powerful and mighty bowing down in fear before the 'small and innocent children'. When he came to himself, he saw that the walls were suddenly filled with images of naked men and women, the latter in all sorts of 'shapes and postures', and he cried out, 'Lord, Lord, I may indeed see everything'. He claimed he was no longer 'vexed or made impure by any created work of God' (i.e. he was now above lust). Now, when he had intercourse with his wife, Dirckgen, it could be purely as a means of producing the pure children of God, untainted by sexual arousal or $\sin .{ }^{60} \mathrm{He}$ finally woke exhausted, picked up his quill, and in this state of ecstasy, wrote one of his first published tracts, Hear, Hear, Hear, Great Wonder, Great Wonder, Great Wonder. ${ }^{61}$ This is a work of excited emotionality, with little regard to logic or clear organization. It is instead filled with bold proclamations, oblique references to himself as the third David who will defeat death, and intense repetition of phrases typical of a town crier.

Joris's ecstatic episodes were often accompanied by physical manifestations. His zeal produced 'inner warmth' that kept him alive even when hiding in unbearably cold rooms. In other cases, the Spirit pressed on him so hard that he 
collapsed from exhaustion and fear of God or stumbled around as if drunk. One time the divine power entered into his head 'like a heavy spiritual burden', giving him 'a perception of or sensitivity to the resurrection', again forcing him into a prone position. In this state, he felt the spirit move about or circulate within his body. ${ }^{62}$ This allowed him to perceive 'five new senses from God' with which, he believed, he could comprehend all aspects of creation in their true, inward meaning. ${ }^{63}$ At least one other disciple, Leonard van Dam, had similar ecstatic experiences about which he published a pamphlet in June 1539. ${ }^{64}$ Such euphoric experiences were commonplace among mystics and visionaries from all confessional camps. There are elements also reminiscent of the writhing of demoniacs, which Sarah Ferber has astutely revealed could be utilized by the afflicted as evidence of spirituality. ${ }^{65}$ For Joris, these episodes produced 'an innocent, restful spirit, [in which] he was set free from all his fantasies or fears,' especially his concerns over his wife's future should he be executed. His new confidence included freedom from worry, anxiety, fear, and 'esteem of the world'. Followers expressed puzzlement that he was suddenly joyful during 'such a sad time'. He responded that he was no longer afraid even of the emperor, who should instead acknowledge Joris as God's agent. ${ }^{66}$

Joris's boldness required frequent testing through moments of danger. Hoping to 'avoid all human things' he also embarked upon a period of intense fasting and prayer that undoubtedly contributed to his frequent visions, but which also nearly killed him, so that followers had to compel him to eat. ${ }^{67}$ Total resignation to God's will (the mystic's Gelassenheit) was his goal. Joris's emotional struggles were exacerbated by pressures to abandon his craft and rely entirely on God for survival; as a fugitive, he found it virtually impossible to complete his commissions, and this was compounded by the conundrum of painting religious images while opposing idolatry. When he quit his profession, followers provided donations; whereas Joris travelled to survive, wrote his treatises, letters, and songs, and met with other Anabaptist groups across the Northern Netherlands, Westphalia, and Strasbourg.

Joris was obviously not the only one experiencing strong feelings; his opponents hated him with a profound passion that they set out in the polemical literature. Jan van Batenburg, leader of a small Anabaptist terrorist cell was 'so envious and evilminded towards him that he would have certainly torn him apart with his teeth', ${ }^{6}$ primarily because Joris won over several Batenburgers to his group; these apparently expected Joris to be revealed as the new king David who would restore the kingdom of Christ three and a half years after the fall of Münster. ${ }^{69}$ In his confession to the authorities in late 1537, Batenburg therefore implicated Joris in his militant schemes. ${ }^{70}$ Despite this, Joris expressed empathy for the Batenburgers' anger, as the biographer notes, 'for they had been made completely despairing, frantic, raging, and insane' by witnessing the judicial murder of a wife, child, husband, parent, or friend, leading to a profound 'spirit of vengeance'. ${ }^{71}$

Once in safe refuge in Antwerp, Joris's visions seem to have ended, undoubtedly because he no longer suffered from the intense fears of a fugitive. He was able to write more frequently, and altered his theology into a much more 
spiritualized approach to religion, turning his earlier apocalyptic denunciations of governmental persecution into more thoughtful pleas for a higher level of religious toleration. Unbound by scholarly logic or confessional orthodoxy, Joris allowed his mind to interpret scripture freely, following the inspiration of the Spirit's voice within. His emotional equilibrium was undoubtedly helped by the protection of his noble patrons, the Van Lier and Van Berchem families of Antwerp. Even when the government discovered his whereabouts in 1544, the support of these families surely reduced his emotional turmoil as they all moved to Basel with a great deal of disposable wealth. ${ }^{72}$

Like many other Neo-Platonists and mystics, Joris told his correspondents to focus on the inner crucifixion of the sinful 'Old Man' and the progressive transformation into the 'New Man' (Figure 6.4). The result would be the transcendence of emotional extremes caused by external forces and peace in the knowledge that one's fate resided solely in God's hands. He also returned to his original vocation as a means of illustrating his writings, such as the designs he created for his Wonder Book c. $1542 .{ }^{73}$ In his depiction of the New Man, we see a naked male in classical pose, with calm visage and with the members of the trinity identified by body parts: God as the head, Christ as the heart, and most interesting, the Holy Spirit or the 'high power of God' as the male genitalia.

There is also a famous portrait of Joris by an unknown Netherlandish artist that was likely commissioned by him, that portrays Joris in a state of calm resolution (Figure 6.5). Joris seems to be pointing to a scene of the good Samaritan over his left shoulder, a major theme in his writings. Hence, his expression is likely also intended to be interpreted as promoting love for neighbour. ${ }^{74}$ In an allegorical glass roundel attributed to Joris, the virtues are similarly self-possessed and calm, as in the depiction of Charity (Figure 6.6).

One of Joris's key themes is the contrast between the fear of God, which is a positive emotion, and the fear of humans, which is negative. The fear of God became profoundly important during the late Middle Ages, leading to increased anxiety over offences committed against the divine. ${ }^{75}$ It was a principal factor in Reformation campaigns to eradicate blasphemy, idolatry, and diabolical heresy and magic. Joris, however, did not emphasize the judgement of God in this, but rather His love. He completely avoided confessional polemics, since external religious trappings were not the things that angered God. Instead, to feel and perform love of neighbour was the single most important emotion for spiritualists.

Apart from the fear of God, Europeans in the sixteenth and seventeenth centuries most feared diabolical witchcraft. As Reformers removed countermagic from the people's arsenal for self-defence against maleficia, they were

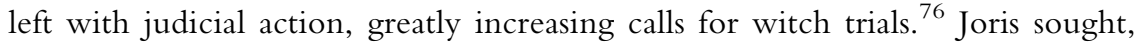
in his peculiar way, to depreciate anxiety over the Devil by reconceiving him not as an external foe, but as the evil inclinations within the individual. ${ }^{77}$ Believers needed to 'cast out Satan' through the public confession of sins, which removed the shame that had become associated with the 


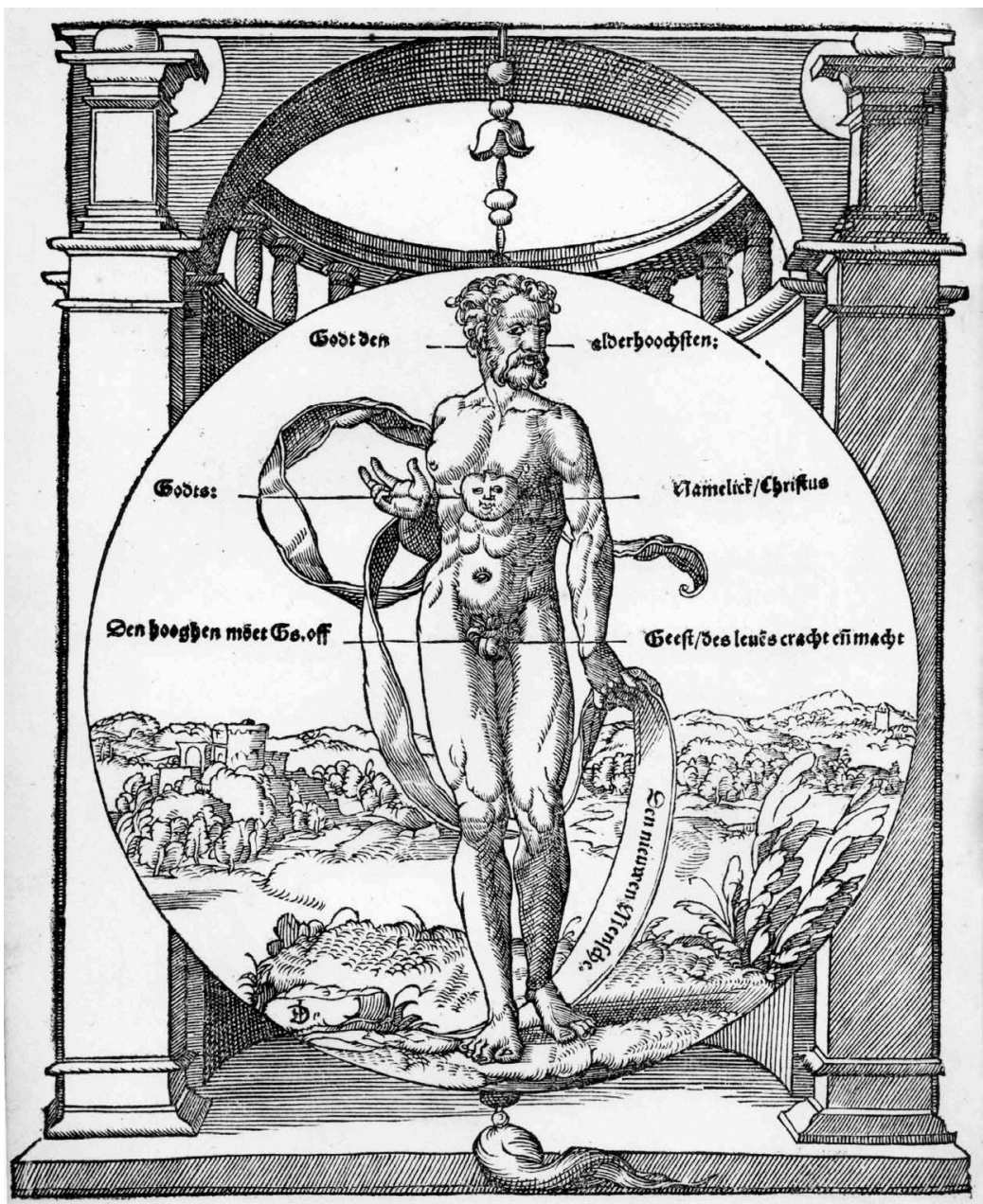

FIGURE 6.4 After David Joris, The New Man, woodcut, in Joris, Twonder Boeck ([Deventer], Dirk van den Borne, 1542-1544), part 2, fol. 211v. Allard Pierson, University of Amsterdam, Kerkelijke Collecties, OG 63-5480.

human body after the fall. For a time, Jorists performed this confession nude in front of the spiritually pure, as a proof of the eradication of sexual shame and lust. ${ }^{78}$ Around 1540 , Joris laid out his new demonology, most explicitly in Behold, the Book of Life is Opened to Me, a work reprinted in 1616 as A Brief and Instructive Tract: Wherein is treated what the word Devil means. ${ }^{79}$ In an unpublished tract, Joris responded to the question of "whether God indeed would allow a sorcerer [tovenaar] to have the ability to debilitate the property or body of the believer'. In reply, Joris first set up a Lutheran straw man, as someone with a strong faith 'according to the letter', who should 


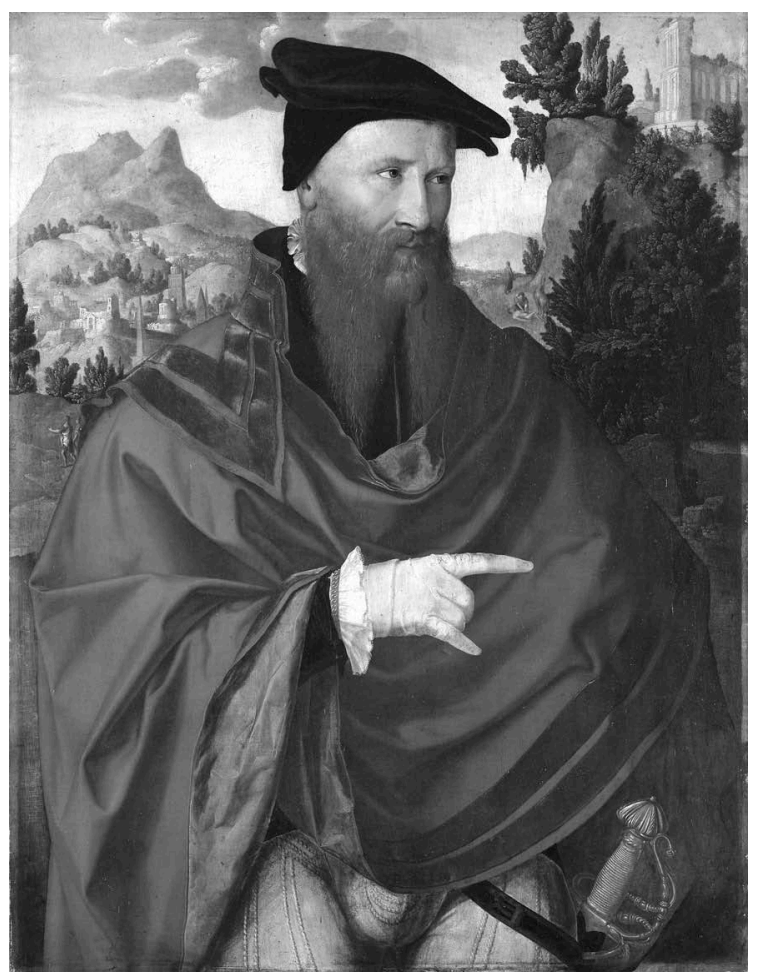

FIGURE 6.5 Frisian School, Portrait of David Joris, c.1550-1555, oil on oak. Kunstmuseum Basel, Inv. 561. Public domain.

reply that God would not allow the Devil so much independent power over believers. He then conceded that while a Lutheran's response was not bad,

it reveals faith only concerned with the protection and preservation of the body. But now God desires to establish a superior, more holy and eternal faith. He therefore might allow a sorcerer or devil such ability to make a person miserable in the body, to damage his outer life and property, thereby proving our faith and love for God, to see if we will believe and trust him less... Meanwhile, he now desires that we forget and pay little heed to all physical welfare, yes, to all that is external, so that we might gain and preserve eternally the inward. So entirely is the Lord's desire and will to plant the most holy faith of eternity in us, that he no longer considers the other at this time. ${ }^{80}$

Hence, even if diabolical witchcraft could harm individuals, such physical damage was of no consequence compared to the inner bewitchment experienced in the soul of those who ignored the Holy Spirit. The inner spirit of the 


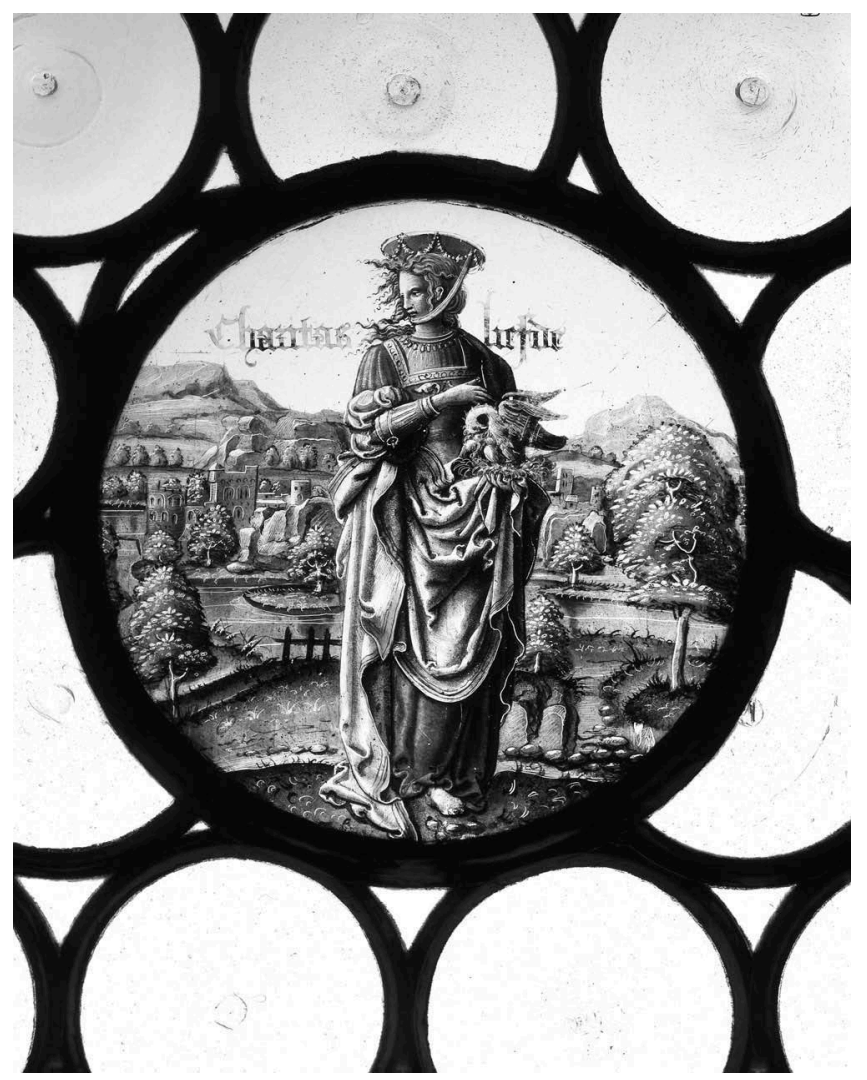

FIGURE 6.6 David Joris (attributed), Charitas/Liefde, c. 1545, glass roundel. Courtesy of the Historisches Museum Basel, 1905.498. Photography by Peter Portner.

regenerate individual could not be harmed by outer magic, however caused. In other letters, he tells the ill to regard their suffering as divine chastisement intended to remove from them their preoccupation with the physical. ${ }^{81}$ In this way, Joris's approach was comparable to that of other mystics and spiritualists, such as the spiritualist Matthias Wier, brother to the physician Johan Wier (Weyer), author of the 1563 De praestigiis daemonum and a correspondent with Joris. $^{82}$

Concerns over the impact of Joris's spiritualism proved a preoccupation among Dutch polemicists throughout the sixteenth and seventeenth centuries but became a major theme in the works of English writers only after they became aware of Joris's unusual demonology in the 1640s when a critical biography of the prophet by Joris's son-in-law Nicolaas Meyndertsz van Blesdijk was published in Latin in $1642 .{ }^{83}$ This led the famed English philosopher, Henry More (1614-87), in his Enthusiasmus triumphatus, not only to critique extreme religious enthusiasm in general, but also to try to explain Joris's wide appeal. Like many other English polemicists, he blamed the Dutch 
prophet for the current surge in spiritualistic groups in England, from the Family of Love to the Quakers. ${ }^{84}$ A Fellow of the Royal Society, More sought to tread a path between excessive rationalism and spiritualism, as well as to prove the reality of the supernatural world against the rising tide of materialistic philosophy. ${ }^{85} \mathrm{He}$ was afraid of the new movements inspiring ordinary women and men to speak with the confidence of the Spirit within, explaining such as arising from 'the enormous strength of Imagination the cause of Enthusiasme'. ${ }^{86}$ He therefore sought a physiological explanation for why so many were falling into the trap of 'Enthusiasme', relying on Galenic humoral theory to do so. Such unconstrained visionaries, he concluded, suffer from Melancholia, an excess of black bile that could imbalance the mind and lead to hallucinations, visions, or revelations. ${ }^{87}$ David George (Joris) was one of these so disturbed by their humoral imbalances, yet More reserves a distinctive diagnosis for him.

More asserts that, along with suffering from bouts of Melancholia, Joris had a 'Sanguine Temper', and was hence susceptible to 'every blast of transient pleasure'. In this temperament, associated with the element of air, are housed 'the fiercer Passions', which combined with a dose of Melancholia explained Joris's allowance of polygamy. ${ }^{88}$ When out of balance, the sanguine temper made Joris susceptible to lust, to religious passions divorced from reason, to excess in both thought and sexual desire. More even compares the Prophet Muhammad favourably to Joris, 'who yet was so highly conceited of his own light, that he hoped to put Mahomet's nose out of joynt'. For, intoxicated by his own 'Melancholy and Sanguine', Joris had the temerity to declare himself 'the last and chiefest prophet', denying heaven, hell, eternal reward or punishment, demons and angels, and the immortality of the soul. 'Though born a Christian, yet he did Mahomitise in this that he also did indulge plurality of wives' ${ }^{89}$ More thus explains Joris's apparent contradiction as a self-proclaimed prophet of God, who at the same time refused to entertain the existence of anything beyond this lifea contradiction arising from a humoral condition in which his sanguine temper was made further unbalanced by melancholic fits. Disposed already to the excessive love of women, Joris thus needed to deny angels and the spirit world to no longer fear eternal judgement. ${ }^{90}$ Although it seems unlikely that More had access to the anonymous biography of Joris, which indeed admitted that Joris had been 'born of the complexion of love', More certainly believed he had evidence for his assertions despite not having read a page of Joris's works. ${ }^{91}$ Joris certainly did struggle with intense feelings, including sexual desire, yet believed that he had found a way to transform these into divine feelings that transcended base physical urges, thanks to the Spirit within. More obviously disagreed.

\section{Conclusion}

Joris's development of a scheme to replace human emotions with purer spiritual versions coincided with his transition away from Anabaptism and towards spiritualism, which strongly emphasized inner spiritual development, focused on the love of God and of one's neighbour, and severely diminished external religiosity. Before his move to Antwerp, Joris struggled intensely to maintain his sanity 
while experiencing feelings of apocalyptic excitement and anxiety so powerful they produced ecstatic, visionary episodes. Hounded by governmental authorities, Joris emphasized the inner renewal of the person that would overwhelm transient human emotions such as fear and anger with divine ones, such as love and forgiveness. Achieving such internal tranquillity required the mortification of the Old Man, which represented human frailties and feelings, and its replacement with the New Man, whose emotions would be infused by the Holy Spirit. This scheme was in some respects reminiscent of classical Stoicism, helping to explain why some humanists and nobles found his ideas, and those of other spiritualists, attractive. ${ }^{92}$ Yet, the major difference between Joris and Stoicism was that Joris's means of achieving calm was through replacing the fear of humans with the fear and love of God; by allowing this to fill one's mind and heart, the believer could no longer be destabilized by anxiety. Many people seem to have found this approach appealing, and along with being a prolific writer, Joris elicited considerable opposition from the orthodox who feared his influence and therefore kept his name and controversial interpretations in the public arena long after he died. Some, such as Henry More, went so far as to diagnose Joris's unorthodox theology by reference to his alleged physiological makeup, which explained what More considered his emotional instability and susceptibility to sexual temptation. More hoped that this diagnosis would steer his readers away from spiritualistic excess.

This one case study of David Joris reveals the great need for more in-depth analysis of the broader role of the emotions in the theological developments and dramatic events of the Reformation. The Reformation unleashed often uncontrollable passions, escalating anger and an array of fears to the point of great violence. Both the prosecuted and the prosecutors were motivated by such feelings to take the actions that they did. From the ecstatic excitement of living in the Last Days to the fear of divine punishment for tolerating blasphemers, emotions played enormously important roles in the debates and decisions of all actors in the Reformation era. The quest for emotional stability was, therefore, a popular one. Like the more famous Puritans, Joris sought emotional peace in knowing that he was one of God's chosen; but unlike them, he advocated the possibility of reaching a state of inner spiritual purity that would allow the children of God to achieve emotional peace and remain unaffected by external temptations or crises, since they were focused on the love provided by the Holy Spirit within. Many humanists found such spiritualism a good religious kin to ancient Stoicism. It is for this reason, and despite the obscurity of his writing style and widespread infamy, that Joris's spiritualism remained popular well into the eighteenth century.

\section{Notes}

1 See for example, Anne Jacobson Schutte, Susan C. Karant-Nunn, and Heinz Schilling, eds, Reformation Research in Europe and North America/Reformationsforschung in Europa und Nordamerika (Gütersloh: Gütersloher Verlagshaus, 2009). 
2 The classic study remains Peter Burke, Popular Culture in Early Modern Europe, revised reprint (Aldershot: Ashgate, 1994). See also Robert Scribner, Popular Culture and Popular Movements in Reformation Germany (London: Hambledon, 1987); and Robert Scribner and Trevor Johnson, eds., Popular Religion in Germany and Central Europe, 1400-1800 (Basingstoke: Palgrave, 1996).

3 Matthew Milner, The Senses and the English Reformation (Farnham: Ashgate, 2011). See also Carlos M. N. Eire, War Against the Idols: The Reformation of Worship from Erasmus to Calvin (Cambridge: Cambridge University Press, 1986); Stuart Clark, Vanities of the Eye: Vision in Early Modern European Culture (Oxford: Oxford University Press, 2007); and Alexandra Walsham, The Reformation of the Landscape: Religion, Identity, \& Memory in Early Modern Britain and Ireland (Oxford: Oxford University Press, 2011).

4 Jonas Liliequist, ed., A History of Emotions, 1200-1800 (London: Pickering and Chatto, 2012), esp. Paola Baseotto, "Theology and Interiority: Emotions as Evidence of the Working of Grace in Elizabethan and Stuart Conversion Narratives," 65-78; William G. Naphy and Penny Roberts, eds, Fear in Early Modern Society (Manchester: Manchester University Press, 1997).

5 Johan Huizinga, The Waning of the Middle Ages: A Study of the Forms of Life, Thought, and Art in France and the Netherlands in the Fourteenth and Fifteenth Centuries, trans. F. Hopman (Harmondsworth: Penguin, 1985). See also Barbara H. Rosenwein, "Theories of Change in the History of Emotions," in A History of Emotions, 1200-1800, ed. Jonas Liliequist (London: Pickering and Chatto, 2012), 7-20, and "Thinking Historically about Medieval Emotions," History Compass 8 (2010): 828-42.

6 Roberts and Naphy, Fear, 1-8; Natalie Zemon Davis, Fiction in the Archives: Pardon Tales and Their Tellers in Sixteenth-Century France (Stanford: Stanford University Press, 1987).

7 See for example, Brian P. Levack, The Witch-Hunt in Early Modern Europe, 4th ed. (Abingdon, Oxon.; New York: Routledge, 2016), 105-7; and H.C. Erik Midelfort, A History of Madness in Sixteenth-Century Germany (Stanford: Stanford University Press, 1999).

8 Natalie Zemon Davis, "The Rites of Violence," in Society and Culture in Early Modern France: Eight Essays by Natalie Zemon Davis (Stanford: Stanford University Press, 1975), 152-87.

9 Nicholas Terpstra, Religious Refugees in the Early Modern World: An Alternative History of the Reformation (Cambridge: Cambridge University Press, 2015); Gary K. Waite, "Sixteenth Century Religious Reform and the Witch-Hunts," in The Oxford Handbook of Witchcraft in Early Modern Europe and Colonial America, ed. Brian Levack (Oxford: Oxford University Press, 2013), 487; Gary K. Waite, Heresy, Magic and Witchcraft in Early Modern Europe (Basingstoke: Palgrave, 2003).

10 John S. Oyer, "The Reformers Condemn the Anabaptists," in "They Harry the Good People Out of the Land': Essays on the Persecution, Survival and Flourishing of Anabaptists and Mennonites, ed. John D. Roth (Goshen: Mennonite Historical Society, 2000), 3-15.

11 Gary K. Waite, "Demonizing Rhetoric, Reformation Heretics and the Witch Sabbaths: Anabaptists and Witches in Elite Discourse," The Devil in Society in the Premodern World, eds. Richard Raiswell and Peter Dendle (Toronto: Centre for Reformation and Renaissance Studies, 2012), 195-219.

12 Heiko A. Oberman, Luther: Man between God and the Devil (New Haven: Yale University Press, 1989), 272-83.

13 Baseotto, "Theology and Interiority," 66-7, 74.

14 Jörg Haugk von Jüchsen, "A Christian Order of a True Christian: Giving Account of the Origin of His Faith," in Sources of South German/Austrian Anabaptism, ed. C. Arnold Snyder (Kitchener: Pandora Press, 2001), 1-23. 
15 Gary K. Waite, Eradicating the Devil's Minions: Anabaptists and Witches in Reformation Europe (Toronto: University of Toronto Press, 2007), 52.

16 Thieleman van Braght, The Bloody Theater or Martyrs Mirror of the Defenseless Christians ... to the Year A.D. 1660, trans. Joseph F. Sohm, 2nd English ed. (Scottdale, PA: Herald Press, 2006). This translation was based on the 1886 English edition which was in turn based on the 1660 Dutch original. On martyrology, see Brad S. Gregory, Salvation at Stake: Christian Martyrdom in Early Modern Europe (Cambridge, MA: Harvard University Press, 2001).

17 Jaap Geraerts, "The Prosecution of Anabaptists in Holland, 1530-1566," Mennonite Quarterly Review 86 (2012): 5-48.

18 Joris requires a new biography, but see Gary K. Waite, David Joris and Dutch Anabaptism, 1524-1543 (Waterloo: Wilfrid Laurier University Press, 1990); Roland Bainton, David Joris. Wiedertäufer und Kämpfer für Toleranz im 16. Jahrhundert (Leipzig: M. Heinsius Nachfolger, 1937) and Samme Zijlstra, Nicolaas Meyndertsz van Blesdijk. Een bijdrage tot de Geschiedenis van het Davidjorisme (Assen: Van Gorcum, 1983).

19 Mirjam van Veen, "Dirck Volckertz Coornhert: Exile and Religious Coexistence," in Exile and Religious Identities, 1500-1800, ed. Jesse Spohnholz and Gary K. Waite (London: Pickering \& Chatto, 2014), 70-71.

20 Hans de Waardt, "Justus Velsius Haganus: An Erudite but Rambling Prophet," in Exile and Religious Identities, 1500-1800, ed. Jesse Spohnholz and Gary K. Waite (London: Pickering \& Chatto, 2014), 97-110. Further on madness, see Midelfort, Madness; and Hans de Waardt, "Lightning Strikes, Wherever Ire Dwells with Power': Johan Wier on Anger as an Illness," in Diseases of the Imagination and Imaginary Disease in the Early Modern Period, ed. Yasmin Haskell (Turnhout: Brepols, 2011), 259-74.

21 James D. Tracy, "Erasmus among the Postmodernists: Dissimulatio, Bonae Literae, and Docta Pietas Revisited," in Erasmus' Vision of the Church, ed. Hilmar M. Pabel (Kirksville: Sixteenth Century Journal, 1995), 1-40. On the early Dutch Evangelicals, see A. C. Duke, Dissident Identities in the Early Modern Low Countries, eds. J. Pollmann and A. Spicer (Farnham: Ashgate, 2009), 55-110 and 144-74.

22 See Ralf Klötzer, "The Melchiorites and Münster," and G. Dipple, "The Spiritualist Anabaptists," in A Companion to Anabaptism and Spiritualism, 1521-1700, ed. John D. Roth and James M. Stayer (Leiden: Brill, 2007), 217-56 and 257-98.

23 Andrew Cunningham and Ole Peter Grell, ed. The Four Horsemen of the Apocalypse: Religion, War, Famine, and Death in Reformation Europe (Cambridge: Cambridge University Press, 2000).

24 Gary K. Waite, "Naked Harlots or Devout Maidens? Images of Anabaptist Women in the Context of the Iconography of Witches in Europe, 1525-1650," in Sisters: Myth and Reality of Anabaptist, Mennonite, and Doopsgezind Women ca 1525-1900, ed. Mirjam van Veen, Piet Visser, and Gary K. Waite (Leiden: Brill, 2014), 17-51. See the court records in Albert F. Mellink, ed., Documenta Anabaptistica Neerlandica, vol. 5, Amsterdam, 1531-1536 (Leiden: Brill, 1985), 109-16.

25 Mellink, Documenta, 5:112.

26 Gary K. Waite, "Apocalyptical Terrorists or a Figment of Governmental Paranoia? Re-Evaluating the Religious Terrorism of Sixteenth-Century Anabaptists in the Netherlands and Holy Roman Empire, 1535-1570," in Grenzen des Täufertums/ Boundaries of Anabaptism: Neue Forschungen, ed. Anselm Schubert, Astrid von Schlachta, and Michael Driedger (Gütersloh: Gütersloher, 2009).

27 Obbe Philips, "A Confession," in Spiritual and Anabaptist Writers, ed. George H. Williams and Angel M. Mergal (Philadelphia: Westminster, 1957), 207-8.

28 Philips, "Confession," 213.

29 Philips, "Confession," 223. 
30 Jans's surname is sometimes misspelled as Jansz, which would be short for Janszoon, or Jan's son. To indicate the gender it should instead be Jansdr.

31 Van Braght, Martyr's Mirror, 453-54. See also Werner O. Packull, "Anna Jansz of Rotterdam, a Historical Investigation of an Early Anabaptist Heroine," Archiv für Reformationsgeschichte 78 (1987): 147-73.

32 Van Braght, Martyr's Mirror, 467-68.

33 Waite, "Apocalyptical Terrorists," 114-15.

34 Waite, Eradicating, 111-12.

35 Only rarely do we possess both court records and a martyrological description of an interrogation; for one such example, see Waite, Eradicating, 71-72.

36 "The Anonymous Biography of Joris," in The Anabaptist Writings of David Joris, 1535-1543, ed. and trans. Gary K. Waite (Waterloo: Herald Press, 1994), 31-103; on the authorship, 31-32. While the original Dutch manuscript is now lost, it was earlier preserved in German as "David Joris sonderbare Lebensbeschreibung," in Gottfried Arnold, Unpartheiische Kirchen- und Ketzer Historie, 2 vols (Frankfurt, 1729; repr., Hildesheim: Georg Olms, 1967), 703-37. On Arnold and Joris, see Douglas H. Shantz, "David Joris, Pietist Saint: The Appeal to Joris in the Writings of Christian Hoburg, Gottfried Arnold and Johann Wilhelm Petersen," Mennonite Quarterly Review 78 (2004): 415-32.

37 "Anonymous Biography," 33-34.

38 "Anonymous Biography," 35.

39 "Anonymous Biography," 36-37. Waite, David Joris and Dutch Anabaptism, 49-51.

40 On Joris as an artist, see K. G. Boon, "De Glasschilder David Joris, een Exponent van het Doperse Geloof. Zijn Kunst en zijn Invloed op Dirck Crabeth," Mededelingen van de Koninklijke Academie voor Wetenschappen, Letteren en Schone Kunsten van België 64 (1988): 117-37. See also Gary K. Waite, "Reconceiving the Senses: The Perspective of the Dutch Spiritualist David Joris (1501-56)," in Embodiment, Expertise, and Ethics in Early Modern Europe: Entangling the Senses, ed. Marlene Eberhart and Jacob Baum (London: Routledge Press, forthcoming).

41 "Anonymous Biography," 38-39; Waite, David Joris and Dutch Anabaptism, 52-54.

42 "Anonymous Biography," 40-41.

43 "Anonymous Biography," 41-42; Waite, David Joris and Dutch Anabaptism, 65-68.

44 David Joris, "O Christian Spirits," in The Anabaptist Writings of David Joris, 1535-1543, ed. and trans. Gary K. Waite (Waterloo: Herald Press, 1994), 107-8; "Anonymous Biography," 42-43.

45 "Anonymous Biography," 75.

46 She claimed not to have been rebaptised. Waite, David Joris and Dutch Anabaptism, 74.

47 Robert J. Lifton, Death in Life: Survivors of Hiroshima (New York: Random House, 1967), 514. In his early writings Joris described death as the work of the Devil that will be defeated by the third David, i.e., Joris. Joris later revised this third David to refer to the Holy Spirit. See David Joris, Twonder-boeck: waer in dat van der Werldt aen versloten gheopenbaert is, 2nd ed. ([Vianen, 1584]), fols. 33r-v; see also chap. 31 on the fall of death and damnation.

48 'You men, arm yourselves well and fight against death, which has for so long hidden in the beggarly lusts of the flesh. Oppose mightily and heartily the invincible serpent and cast death away from you into the hell of the abyss'. David Joris, Hoert, hoert, hoert, Groot wunder/groot wunder/groot wunder ([Antwerp, c.1540]), fols. 3v-4r; David Joris, "Hear, Hear, Hear, Great Wonder, Great Wonder, Great Wonder, 1536," in The Anabaptist Writings of David Joris, 1535-1543, ed. and trans. Gary K. Waite (Waterloo: Herald Press, 1994), 138.

49 "Anonymous Biography," 102.

50 "Anonymous Biography," 46.

51 "Anonymous Biography," 47-48.

52 “Anonymous Biography," 50.

53 “Anonymous Biography," 82-84, 93-98. 
54 "Anonymous Biography," 47.

55 “Anonymous Biography," 50.

56 Midelfort, Madness, 6-7, 10, 14. Joris's biographer often describes his feelings as if they were forces external to the man.

57 "Anonymous Biography," 51, 65-66. The biographer admits that Joris did "fall just like any other sinner in this, more than he would have liked. For he was easily overcome when anyone showed affection to him'. See Zijlstra, Blesdijk, 17.

58 "Anonymous Biography," 52.

59 On Joris and Jews, see Gary K. Waite, "Conversos and Spiritualists in Spain and the Netherlands: The Experience of Inner Exile, c.1540-1620," in Exile and Religious Identities, 1500-1800, ed. Jesse Spohnholz and Gary K. Waite (London: Pickering \& Chatto, 2014), 162-63.

60 "Anonymous Biography," 56. This was in some respects a logical extension of St Augustine's view that before the Fall sexual congress was a rational act, without any hint of sexual passion. See Elaine Pagels, Adam, Eve, and the Serpent (New York: Random House, 1988), 109-12.

61 Joris, Hoert, hoert, hoert.

62 "Anonymous Biography," 57.

63 "Anonymous Biography," 84. See Waite, "Reconceiving the Senses."

64 "Anonymous Biography," 87-90. I have included a translation of this passage in Waite, David Joris and Dutch Anabaptism, 203-6.

65 Many demoniacs 'felt' the demon moving from one part of their body to another. See, for example, the case of Nicole Obry in 1566: Sarah Ferber, Demonic Possession and Exorcism in Early Modern France (London: Routledge, 2004), 30-32.

66 "Anonymous Biography," 55.

67 "Anonymous Biography," 58.

68 "Anonymous Biography," 63.

69 Willem de Bakker and Gary K. Waite, "Rethinking the Murky World of the PostMünster Dutch Anabaptist Movement, 1535-1538: A Dialogue between Willem de Bakker and Gary K. Waite," Mennonite Quarterly Review 92 (2018): 47-91.

70 Waite, David Joris and Dutch Anabaptism, 116-20; Waite, "Apocalyptical Terrorists."

71 “Anonymous Biography," 73.

72 Waite, David Joris and Dutch Anabaptism, 177-92. The best works on Joris's Basel years remain Bainton, David Joris and P. Burckhardt, "David Joris und seine Gemeinde in Basel," Basler Zeitschrift für Geschichte und Altertumskunde 48 (1949): 5-106.

73 David Joris, Twonder Boeck (Deventer, 1542/3). These were turned into more sophisticated engravings in the second edition of 1551 which was printed for the first time in the 1580s.

74 Boon, "De Glasschilder David Joris," 133-35.

75 John Bossy, "Moral Arithmetic: Seven Sins into Ten Commandments," in Conscience and Casuistry in Early Modern Europe, ed. Edmund Leites (Cambridge: Cambridge University Press, 1988), 215-30. See also Waite, Heresy, 45-47.

76 Levack, Witch-Hunt, 107-9.

77 Gary K. Waite, "'Man is a Devil to Himself: David Joris and the Rise of a Sceptical Tradition Towards the Devil in the Early Modern Netherlands, 1540-1600," Nederlands Archief voor Kerkgeschiedenis/Dutch Review of Church History 75 (1995): 1-30.

78 For this practice, see Zijlstra, Blesdijk, 32. Joris provided a formula for the act of exorcising this inner devil from oneself: 'Go away from me, Satan, or I shall shame you in all your counsel. You deceitful devil and evil spirit, depart. See, I shall reveal all your lies, roguishness and deceit. I will take off your clothes, I will no longer conceal your bidding, no longer do your will and desires. Therefore go far from me, for the Lord, the Mighty One, the Holy One in Israel, is my love and bridegroom and husband, whose eyes keep me in his presence, and make me content'. Joris, Hoert, hoert, hoert, $21^{\mathrm{v}}$. 
79 David Joris, Een Cort ende Leerlijck Tractaat: waer in verhandelt wert/wat dat woort Duyvel sy/ende hoe men 'tselvighe in die H. Schrift verstaen sal ([Netherlands], 1616); original version: Neemt Waer. Dat boeck des leuens/is mi gheopenbaert ([Antwerp, c.1540]). On Joris's printers, see Paul Valkema Blouw, "Printers to the 'Arch-Heretic' David Joris: Prolegomena to a Bibliography of His Works," Quarendo 21 (1991): 163-209. Joris similarly reinterpreted learned magic following his spiritualistic motif, so that the true meaning of alchemy or the Kabbalah was not the manipulation of occult powers, but as a metaphor for personal spiritual transformation. Gary K. Waite, "An Artisan's Worldview? David Joris, Magic and the Cosmos," in Commoners and Community: Essays in Honour of Werner O. Packull, ed. C. Arnold Snyder (Kitchener: Pandora Press, 2002), 167-94.

80 David Joris, "Vrage. Of God wel toelaten solde, dat een Tovenaer macht hadde/die Geloovigen aen hare haeve of lichaem te bekrencken," unpublished ms, n.d., HS 65-82, fols. $68 \mathrm{r}-71 \mathrm{v}$, Universiteitsbibliotheek, Universiteit van Amsterdam.

81 For an example, see Gary K. Waite, "Demonic Affliction or Divine Chastisement? Conceptions of Illness and Healing Amongst Spiritualists and Mennonites in Holland, c.1530-c.1630," in Illness and Healing Alternatives in Western Europe, ed. Marijke Gijswijt-Hofstra, Hilary Marland, and Hans de Waardt (London: Routledge, 1997), 62-63.

82 Hans de Waardt, "Witchcraft, Spiritualism and Medicine: The Religious Convictions of Johan Wier," Sixteenth Century Journal 42 (2011): 369-91; Gary K. Waite, "Radical Religion and the Medical Profession: The Spiritualist David Joris and the Brothers Weyer (Wier)," in Radikalität und Dissent im 16. Jahrhundert/Radicalism and Dissent in the Sixteenth Century, ed. Hans-Jürgen Goertz and James M. Stayer (Berlin: Dunker \& Humblot, 2002), 167-85.

83 Nicolaas Meyndertsz van Blesdijk, Historia vitae, doctrinae, ac rerum gestarum Davidis Georgii haeresiarchae (Deventer, 1642).

84 Henry More Enthusiasmus triumphatus, or, A discourse of the nature, causes, kinds, and cure, of enthusiasme; written by Philophilus Parresiastes, and prefixed to Alazonomastix his observations and reply (London, 1656). More's use of Joris had been earlier noted by Clark, Vanities of the Eye, 161; and Catherine Wilson, "Enthusiasm and its Critics: Historical and Modern Perspectives," History of European Ideas 17 (1993): 461-78, esp. 462-65, but without any reference to its significance for the reception of Joris. Further on More and enthusiasm, see the essays in Sarah Hutton ed., Henry More (1614-1617) Tercentenary Studies (Dordrecht: Springer, 1990); and Robert Crocker, Henry More, 1614-1617: A Biography of a Cambridge Platonist (Dordrecht: Springer, 2013). Further on enthusiasm and rationalism in the era, see Lawrence Eliot Klein, and Anthony J. LaVopa, Enthusiasm and Enlightenment in Europe, 1650-1850 (San Marino, CA: Huntington Library, 1998). I am currently working on the reception of Joris in England.

85 See Euan Cameron, Enchanted Europe: Superstition, Reason, E Religion, 1250-1750 (Oxford: Oxford University Press, 2010), 275-82.

86 More Enthusiasmus triumphatus, A3v.

87 For the fuller list of those so afflicted, such as Paracelsus, see More, Enthusiasmus triumphatus, A3v-A8v.

88 More, Enthusiasmus triumphatus, 35-36, 183.

89 More, Enthusiasmus triumphatus, 22.

90 More, Enthusiasmus triumphatus, 36.

91 “Anonymous Biography," 68.

92 On Stoicism, see M. Graver, Stoicism and Emotion (Chicago: University of Chicago Press, 2007). On Joris and humanists, see Mirjam van Veen, "'Contaminated with David Joris's Blasphemies': David Joris's Contribution to Castellio's 'De haereticis an sint persequendi'," Bibliothèque d'Humanisme et Renaissance 69 (2007): 313-26. 


\section{Bibliography}

Bainton, Roland. David Joris. Wiedertäufer und Kämpfer für Toleranz im 16. Jahrhundert. Leipzig, 1937.

Bakker, Willem de, and Gary K. Waite. "Rethinking the Murky World of the PostMünster Dutch Anabaptist Movement, 1535-1538: A Dialogue between Willem de Bakker and Gary K. Waite.” Mennonite Quarterly Review 92 (2018): 47-91.

Blesdijk, Nicolaas Meyndertsz van. Historia vitae, doctrinae, ac rerum gestarum Davidis Georgii haeresiarchae. Deventer, 1642.

Boon, K. G. "De Glasschilder David Joris, een Exponent van het Doperse Geloof. Zijn Kunst en zijn Invloed op Dirck Crabeth." Mededelingen van de Koninklijke Academie voor Wetenschappen, Letteren en Schone Kunsten van België 64 (1988): 117-37.

Bossy, John. "Moral Arithmetic: Seven Sins into Ten Commandments." In Conscience and Casuistry in Early Modern Europe, edited by Edmund Leites, 215-30. Cambridge: Cambridge University Press, 1988.

Braght, Thieleman van. The Bloody Theater or Martyrs Mirror of the Defenseless Christians. 2nd ed. Edited and translated by Joseph F. Sohm from the 1886 English edition. Waterloo: Herald Press, 2006.

Burckhardt, P. "David Joris und seine Gemeinde in Basel." Basler Zeitschrift für Geschichte und Altertumskunde 48 (1949): 5-106.

Burke, Peter. Popular Culture in Early Modern Europe. Revised edition. Aldershot: Ashgate, 1994.

Cameron, Euan. Enchanted Europe: Superstition, Reason, E Religion, 1250-1750. Oxford: Oxford University Press, 2010.

Clark, Stuart. Vanities of the Eye: Vision in Early Modern European Culture. Oxford: Oxford University Press, 2007.

Cunningham, Andrew, and Ole Peter Grell, eds. The Four Horsemen of the Apocalypse: Religion, War, Famine, and Death in Reformation Europe. Cambridge: Cambridge University Press, 2000.

Davis, Natalie Zemon. "The Rites of Violence." In Society and Culture in Early Modern France: Eight Essays, 152-87. Stanford: Stanford University Press, 1975.

Davis, Natalie Zemon. Fiction in the Archives: Pardon Tales and Their Tellers in SixteenthCentury France. Stanford: Stanford University Press, 1987.

Duke, A. C. Dissident Identities in the Early Modern Low Countries. Edited by J. Pollmann and A. Spicer. Farnham: Ashgate, 2009.

Eire, Carlos M. N. War against the Idols: The Reformation of Worship from Erasmus to Calvin. Cambridge: Cambridge University Press, 1986.

Ferber, Sarah. Demonic Possession and Exorcism in Early Modern France. London: Routledge, 2004.

Geraerts, Jaap. “The Prosecution of Anabaptists in Holland, 1530-1566.” Mennonite Quarterly Review 86 (2012): 5-48.

Graver, M. Stoicism and Emotion. Chicago: University of Chicago Press, 2007.

Gregory, Brad S. Salvation at Stake: Christian Martyrdom in Early Modern Europe. Cambridge, MA: Harvard University Press, 2001.

Huizinga, Johan. The Waning of the Middle Ages: A Study of the Forms of Life, Thought, and Art in France and the Netherlands in the Fourteenth and Fifteenth Centuries. Translated by F. Hopman. Harmondsworth: Penguin, 1985.

Joris, David. Hoert, hoert hoert, Groot wunder/groot wunder/groot wunder. [Antwerp, c.1540]. Joris, David. Neemt Waer. Dat boeck des leuens/is mi gheopenbaert. [Antwerp, c.1540]. 
Joris, David. Twonder Boeck. Deventer: Dirk von Borne, 1542/3.

Joris, David. Twonder-boeck: waer in dat van der Werldt aen versloten gheopenbaert is. 2nd ed. 1551. Reprinted [Vianen, 1584].

Joris, David. Een Cort ende Leerlijck Tractaat: waer in verhandelt wert/wat dat woort Duyvel sy/ ende hoe men 'tselvighe in die H. Schrift verstaen sal. Netherlands, 1616.

Jüchsen, Jörg Haugk von. "A Christian Order of a true Christian: Giving Account of the Origin of His Faith." In Sources of South German/Austrian Anabaptism, edited by C. Arnold Snyder, 1-23. Kitchener: Pandora Press, 2001.

Levack, Brian P. The Witch-Hunt in Early Modern Europe. 4th ed. Abingdon, Oxon; New York: Routledge, 2016.

Lifton, Robert J. Death in Life: Survivors of Hiroshima. New York: Random House, 1967.

Liliequist, Jonas ed. A History of Emotions, 1200-1800. London: Pickering and Chatto, 2012.

Mellink, Albert F. ed. Documenta Anabaptistica Neerlandica. Vol. 5, Amsterdam, 1531-1536. Leiden: Brill, 1985.

Midelfort, H. C. Erik. A History of Madness in Sixteenth-Century Germany. Stanford: Stanford University Press, 1999.

Milner, Matthew. The Senses and the English Reformation. Farnham: Ashgate, 2011.

More, Henry. Enthusiasmus triumphatus, or, A discourse of the nature, causes, kinds, and cure, of enthusiasme; written by Philophilus Parresiastes, and prefixed to Alazonomastix his observations and reply. London, 1656.

Naphy William G., and Penny Roberts, eds. Fear in Early Modern Society. Manchester: Manchester University Press, 1997.

Oberman, Heiko A. Luther: Man between God and the Devil. New Haven: Yale University Press, 1989.

Oyer, John S. "The Reformers Condemn the Anabaptists." In 'They Harry the Good People Out of the Land': Essays on the Persecution, Survival and Flourishing of Anabaptists and Mennonites, edited by John D. Roth, 3-15. Goshen: Mennonite Historical Society, 2000.

Packull, Werner O. "Anna Jansz of Rotterdam, a Historical Investigation of an Early Anabaptist Heroine." Archiv für Reformationsgeschichte 78 (1987): 147-73.

Pagels, Elaine. Adam, Eve, and the Serpent. New York: Random House, 1988.

Philips, Obbe. "A Confession." In Spiritual and Anabaptist Writers, edited by George H. Williams and Angel M. Mergal, 204-25. Philadelphia: Westminster, 1957.

Rosenwein, Barbara H. "Thinking Historically About Medieval Emotions." History Compass 8 (2010): 828-42.

Roth John D., and James M. Stayer, eds. A Companion to Anabaptism and Spiritualism, 15211700. Leiden: Brill, 2007.

Schutte, Anne Jacobson, Susan C. Karant-Nunn, and Heinz Schilling, eds. Reformation Research in Europe and North America/Reformationsforschung in Europa und Nordamerika: A Historical Assessment. Archive of Reformation History 100. Gütersloh: Gütersloher Verlagshaus, 2009.

Scribner, Robert. Popular Culture and Popular Movements in Reformation Germany. London: Hambledon, 1987.

Scribner, Robert and Trevor Johnson, eds. Popular Religion in Germany and Central Europe, 1400-1800. Basingstoke: Palgrave, 1996.

Shantz, Douglas H. "David Joris, Pietist Saint: The Appeal to Joris in the Writings of Christian Hoburg, Gottfried Arnold and Johann Wilhelm Petersen." Mennonite Quarterly Review 78 (2004): 415-32. 
Spohnholz, Jesse and Gary K. Waite, eds. Exile and Religious Identities, 1500-1800. London: Pickering \& Chatto, 2014.

Terpstra, Nicholas. Religious Refugees in the Early Modern World: An Alternative History of the Reformation. Cambridge: Cambridge University Press, 2015.

Tracy, James D. "Erasmus among the Postmodernists: Dissimulatio, Bonae Literae, and Docta Pietas Revisited." In Erasmus' Vision of the Church, edited by Hilmar M. Pabel, 1-40. Kirksville: Sixteenth Century Journal, 1995.

Valkema Blouw, Paul. "Printers to the 'Arch-Heretic' David Joris: Prolegomena to a Bibliography of His Works.” Quarendo 21 (1991): 163-209.

Veen, Mirjam van. “'Contaminated with David Joris's Blasphemies': David Joris's Contribution to Castellio's De haereticis an sint persequendi." Bibliothèque d'Humanisme et Renaissance 69 (2007): 313-26.

Waardt, Hans de. "'Lightning Strikes, Wherever Ire Dwells with Power': Johan Wier on Anger as an Illness." In Diseases of the Imagination and Imaginary Disease in the Early Modern Period, edited by Yasmin Haskell, 259-74. Turnhout: Brepols, 2011.

Waardt, Hans de. "Witchcraft, Spiritualism and Medicine: The Religious Convictions of Johan Wier." Sixteenth Century Journal 42 (2011): 369-91.

Waite, Gary K. David Joris and Dutch Anabaptism, 1524-1543. Waterloo: Wilfrid Laurier University Press, 1990.

Waite, Gary K., ed. and trans. The Anabaptist Writings of David Joris, 1535-1543. Waterloo: Herald Press, 1994.

Waite, Gary K. "'Man is a Devil to Himself: David Joris and the Rise of a Sceptical Tradition Towards the Devil in the Early Modern Netherlands, 1540-1600." Nederlands Archief voor Kerkgeschiedenis/Dutch Review of Church History 75 (1995): 1-30.

Waite, Gary K. "Demonic Affliction or Divine Chastisement? Conceptions of Illness and Healing Amongst Spiritualists and Mennonites in Holland, c.1530-c.1630." In Illness and Healing Alternatives in Western Europe, edited by Marijke Gijswijt-Hofstra, Hilary Marland, and Hans de Waardt, 59-79. London: Routledge, 1997.

Waite, Gary K. "An Artisan's Worldview? David Joris, Magic and the Cosmos." In Commoners and Community: Essays in Honour of Werner O. Packull, edited by C. Arnold Snyder, 167-94. Kitchener: Pandora Press, 2002.

Waite, Gary K. "Radical Religion and the Medical Profession: The Spiritualist David Joris and the Brothers Weyer (Wier)." In Radikalität und Dissent im 16. Jahrhundert/Radicalism and Dissent in the Sixteenth Century, edited by Hans-Jürgen Goertz and James M. Stayer, 167-85. Berlin: Duncker \& Humblot, 2002.

Waite, Gary K. Heresy, Magic and Witchcraft in Early Modern Europe. Basingstoke: Palgrave, 2003.

Waite, Gary K. Eradicating the Devil's Minions: Anabaptists and Witches in Reformation Europe. Toronto: University of Toronto Press, 2007.

Waite, Gary K. "Apocalyptical Terrorists or a Figment of Governmental Paranoia? ReEvaluating the Religious Terrorism of Sixteenth-Century Anabaptists in the Netherlands and Holy Roman Empire, 1535-1570." In Grenzen des Täufertums/Boundaries of Anabaptism: Neue Forschungen, edited by Anselm Schubert, Astrid von Schlachta, and Michael Driedger, 105-205. Gütersloh: Gütersloher, 2009.

Waite, Gary K. "Demonizing Rhetoric, Reformation Heretics and the Witch Sabbaths: Anabaptists and Witches in Elite Discourse," In The Devil in Society in the Premodern World, edited by Richard Raiswell and Peter Dendle, 195-219. Toronto: Centre for Reformation and Renaissance Studies, 2012. 
Waite, Gary K. "Sixteenth Century Religious Reform and the Witch-Hunts." In The Oxford Handbook of Witchcraft in Early Modern Europe and Colonial America, edited by Brian Levack, 485-506. Oxford: Oxford University Press, 2013.

Waite, Gary K. "Naked Harlots or Devout Maidens? Images of Anabaptist Women in the Context of the Iconography of Witches in Europe, 1525-1650." In Sisters: Myth and Reality of Anabaptist, Mennonite, and Doopsgezind Women ca 1525-1900, edited by Mirjam van Veen, Piet Visser, and Gary K. Waite, 17-51. Leiden: Brill, 2014.

Waite, Gary K. "Reconceiving the Senses: The Perspective of the Dutch Spiritualist David Joris (1501-56)." In Embodiment, Expertise, and Ethics in Early Modern Europe: Entangling the Senses, edited by Marlene Eberhart and Jacob Baum. London: Routledge Press, forthcoming.

Walsham, Alexandra. The Reformation of the Landscape: Religion, Identity, \& Memory in Early Modern Britain and Ireland. Oxford: Oxford University Press, 2011.

Zijlstra, Samme. Nicolaas Meyndertsz van Blesdijk. Een bijdrage tot de Geschiedenis van het Davidjorisme. Assen: Van Gorcum, 1983. 